\title{
Front Matter: Volume 7355
}

, "Front Matter: Volume 7355," Proc. SPIE 7355, Photon Counting Applications, Quantum Optics, and Quantum Information Transfer and Processing II, 735501 (23 June 2009); doi: 10.1117/12.834856

SPIE. Event: SPIE Optics + Optoelectronics, 2009, Prague, Czech Republic 


\title{
PROCEEDINGS OF SPIE
}

\section{Photon Counting Applications, Quantum Optics, and Quantum Information Transfer and Processing II}

\author{
Ivan Prochazka \\ Roman Sobolewski \\ Miloslav Dusek \\ Editors
}

20-21 April 2009

Prague, Czech Republic

Sponsored by

SPIE Europe

Cooperating Organizations

Institute of Physics, Academy of Sciences (Czech Republic)

Department of X-Ray Lasers, Institute of Physics (Czech Republic)

Czech and Slovak Society for Photonics

Photonics Society of Poland (Poland)

Published by

SPIE

Volume 7355 
The papers included in this volume were part of the technical conference cited on the cover and title page. Papers were selected and subject to review by the editors and conference program committee. Some conference presentations may not be available for publication. The papers published in these proceedings reflect the work and thoughts of the authors and are published herein as submitted. The publisher is not responsible for the validity of the information or for any outcomes resulting from reliance thereon.

Please use the following format to cite material from this book:

Author(s), "Title of Paper," in Photon Counting Applications, Quantum Optics, and Quantum Information Transfer and Processing II, edited by Ivan Prochazka, Roman Sobolewski, Miloslav Dusek, Proceedings of SPIE Vol. 7355 (SPIE, Bellingham, WA, 2009) Article CID Number.

ISSN 0277-786X

ISBN 9780819476296

Published by

SPIE

P.O. Box 10, Bellingham, Washington 98227-0010 USA

Telephone +1 3606763290 (Pacific Time) · Fax +1 3606471445

SPIE.org

Copyright (C) 2009, Society of Photo-Optical Instrumentation Engineers

Copying of material in this book for internal or personal use, or for the internal or personal use of specific clients, beyond the fair use provisions granted by the U.S. Copyright Law is authorized by SPIE subject to payment of copying fees. The Transactional Reporting Service base fee for this volume is $\$ 18.00$ per article (or portion thereof), which should be paid directly to the Copyright Clearance Center (CCC), 222 Rosewood Drive, Danvers, MA 01923. Payment may also be made electronically through CCC Online at copyright.com. Other copying for republication, resale, advertising or promotion, or any form of systematic or multiple reproduction of any material in this book is prohibited except with permission in writing from the publisher. The CCC fee code is 0277-786X/09/ $\$ 18.00$.

Printed in the United States of America.

Publication of record for individual papers is online in the SPIE Digital Library.

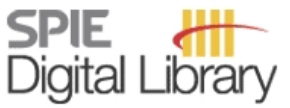

SPIEDigitalLibrary.org

Paper Numbering: Proceedings of SPIE follow an e-First publication model, with papers published first online and then in print and on CD-ROM. Papers are published as they are submitted and meet publication criteria. A unique, consistent, permanent citation identifier (CID) number is assigned to each article at the time of the first publication. Utilization of CIDs allows articles to be fully citable as soon they are published online, and connects the same identifier to all online, print, and electronic versions of the publication. SPIE uses a six-digit CID article numbering system in which:

- The first four digits correspond to the SPIE volume number.

- The last two digits indicate publication order within the volume using a Base 36 numbering system employing both numerals and letters. These two-number sets start with 00, 01, 02, 03, 04, $05,06,07,08,09,0 A, 0 B \ldots 0 Z$, followed by 10-1Z, 20-2Z, etc.

The CID number appears on each page of the manuscript. The complete citation is used on the first page, and an abbreviated version on subsequent pages. Numbers in the index correspond to the last two digits of the six-digit CID number. 


\section{Contents}

vii Conference Committees

\section{PART A Quantum Optics and Quantum Information Transfer and Processing}

\section{PLENARY SESSION}

735502 Photon physics: from wave mechanics to quantum electrodynamics (Plenary Paper) [7355-100]

O. Keller, Aalborg Univ. (Denmark)

\section{QUANTUM CRYPTOGRAPHY AND QUANTUM INFORMATION PROCESSING}

735507 Quantum interference by coherence transfer from spin to orbital angular momentum of photons [7355A-05]

E. Nagali, F. Sciarrino, L. Sansoni, Univ. degli Studi di Roma, La Sapienza (Italy); F. De Martini, Univ. degli Studi di Roma, La Sapienza (Italy) and Accademia Nazionale dei Lincei (Italy); L. Marrucci, B. Piccirillo, Univ. degli Studi di Napoli Federico II (Italy) and CNR-INFM Coherentia, Univ. Monte Sant'Angelo (Italy); E. Karimi, Univ. degli Studi di Napoli Federico II (Italy); E. Santamato, Univ. degli Studi di Napoli Federico II (Italy) and CNR-INFM Coherentia, Univ. Monte Sant'Angelo (Italy)

\section{QUANTUM ENTANGLEMENT AND QUANTUM OPTICS}

735508 Micro-macro entangled photon systems: results and perspectives [7355A-06] C. Vitelli, N. Spagnolo, F. Sciarrino, Univ. degli Studi di Roma, La Sapienza (Italy); F. De Martini, Univ. degli Studi di Roma, La Sapienza (Italy) and Accademia Nazionale dei Lincei (Italy)

735509 X-entanglement of PDC photon pairs [7355A-07]

L. Caspani, E. Brambilla, O. Jedrkiewicz, L. A. Lugiato, A. Gatti, INFM-CNR-CNISM, Univ. degli Studi dell'Insubria (Italy)

$7355 \mathrm{OB}$ Complete bi-partite CV entanglement characterization via coveriance matrix measurement [7355A-09]

A. Porzio, CNR-INFM Coherentia, Univ. Monte Sant'Angelo (Italy); V. D'Auria, CNR-INFM Coherentia, Univ. Monte Sant'Angelo (Italy) and Univ. degli Studi di Napoli Federico II (Italy); S. Fornaro, Univ. degli Studi di Napoli Federico II (Italy); S. Solimeno, CNR-INFM Coherentia, Univ. Monte Sant'Angelo (Italy) and Univ. degli Studi di Napoli Federico II (Italy) 
7355 OC Wafer fused InP-GaAs optically pumped semiconductor disk laser operating at $\mathbf{1 . 5 7} \mu \mathrm{m}$ [7355A-10]

J. Lyytikäinen, J. Rautiainen, Tampere Univ. of Technology (Finland); A. Sirbu, A. Mereuta,

A. Caliman, E. Kapon, Ecole Polytechnique Fédérale de Lausanne (Switzerland);

O. Okhotnikov, Tampere Univ. of Technology (Finland)

7355 OD Quantum well heterostructures studied by deep-level transient spectroscopy [7355A-14] J. Kosíková, Institute of Physics AS (Czech Republic); K. Žd'ánský, Institute of Photonics and Electronics AS (Czech Republic); A. Rudra, E. Kapon, Ecole Polytechnique Fédérale de Lausanne (Switzerland)

\section{PART B Photon Counting Applications}

\section{SEMICONDUCTING PHOTON COUNTERS}

7355 OM Avalanche photodiode output pulse rise-time study (Invited Paper) [7355B-20]

J. Blazej, I. Prochazka, Czech Technical Univ. in Prague (Czech Republic)

$7355 \mathrm{ON}$ High gain and low excess noise near infrared single photon avalanche detector [7355B-21]

K. Linga, Y. Yevtukhov, B. Liang, Amplification Technologies, Inc. (United States)

735500 Simulation modelling for the analysis and the optimal design of SPAD detectors for time-resolved fluorescence measurements [7355B-22]

M. Repich, Univ. of Trento (Italy) and Fondazione Bruno Kessler (Italy); D. Stoppa, L. Pancheri, Fondazione Bruno Kessler (Italy); G.-F. Dalla Betta, Univ. of Trento (Italy)

7355 OP Dynamic range of submicron/nanoparticle sizing with photon correlation LDA [7355B-23]

L. Vámos, P. Jani, Research Institute for Solid State Physics and Optics (Hungary)

\section{PHOTON COUNTING APPLICATIONS}

$7355 \mathrm{OR} \quad$ Very fast photon counting photometers for astronomical applications: IquEYE for the ESO 3.5m New Technology Telescope [7355B-25]

C. Barbieri, Univ. of Padova (Italy); G. Naletto, Univ. of Padova (Italy) and CNR-INFM-LUXOR, Univ. of Padova (Italy); I. Capraro, T. Occhipinti, E. Verroi, P. Zoccarato, Univ. of Padova (Italy); C. Facchinetti, Univ. of Padova (Italy) and Italian Space Agency (Italy); C. Germanà, M. Parrozzani, M. Zaccariotto, G. Anzolin, F. Tamburini, Univ. of Padova (Italy); A. Di Paola, E. Giro, G. Bonanno, S. Billotta, C. Pernechele, P. Bolli, L. Zampieri, A. Possenti, Astrophysical Observatories of Cagliari (Italy); A. Čadez, Univ. of Ljubljana (Slovenia)

7355 OS Multilayer cloud monitoring by micro-Joule lidar based on photon counting receiver and diode laser [7355B-26]

S. M. Pershin, Prokhorov General Physics Institute (Russian Federation); A. N. Lyash,

V. S. Makarov, Space Research Institute (Russian Federation); K. Hamal, I. Prochazka,

B. Sopko, Czech Technical Univ. in Prague (Czech Republic)

7355 OT Observing variable stars and transiting exo-planets with single photon counting [7355B-27] G. Kirchner, F. Koidl, Austrian Academy of Sciences (Austria); A. Dusleag, F. labal, E. Leitgeb, Technische Univ. Graz (Austria) 
7355 OU Graz kHz SLR LIDAR: first results [7355B-28]

G. Kirchner, F. Koidl, D. Kucharski, Institute for Space Research (Austria); W. Pachler, M. Seiss, E. Leitgeb, Technical Univ. Graz (Austria)

7355 OV Monolithic time-to-amplitude converter for photon timing applications [7355B-29]

D. Resnati, I. Rech, M. Ghioni, S. Cova, Politecnico di Milano (Italy)

\section{SEMICONDUCTOR PHOTON DETECTORS}

7355 OW SPAD active quenching circuit optimized for satellite laser ranging applications [7355B-30] J. Kodet, I. Prochazka, Czech Technical Univ. in Prague (Czech Republic); F. Koidl, G. Kirchner, Institute for Space Research (Austria); M. Wilkinson, NERC Space Geodesy Facility (United Kingdom)

7355 0X Modeling photon detection efficiency and temporal response of single photon avalanche diodes [7355B-31]

A. Gulinatti, I. Rech, S. Fumagalli, M. Assanelli, Politecnico di Milano (Italy); M. Ghioni, S. D. Cova, Politecnico di Milano (Italy) and Micro-Photon-Devices (Italy)

$73550 Z$ The development of extremely low noise InAs electron APDs for photon counting applications in SWIR/MWIR wavelengths [7355B-33]

C. H. Tan, A. Marshall, M. J. Steer, J. P. R. David, The Univ. of Sheffield (United Kingdom)

735511 Sensitivity of a receiver using GalnAsSb/AIGaAsSb SAM avalanche photodiode for longwavelength optical communication systems in the mid-infrared spectral range [7355B-35] M. P. Mikhailova, I. A. Andreev, E. V. Kunitsyna, Yu. P. Yakovlev, loffe Physico-Technical Institute (Russian Federation)

Author Index 
Downloaded From: https://www.spiedigitallibrary.org/conference-proceedings-of-spie on 26 Apr 2023

Terms of Use: https://www.spiedigitallibrary.org/terms-of-use 


\title{
Conference Committees
}

\author{
Symposium Chairs
}

Pavel Tomanek, Brno University of Technology (Czech Republic)

Alan Michette, King's College London (United Kingdom)

Bahaa Saleh, Boston University (United States)

Symposium Honorary Chair

Jan Perina, Sr., Palacký University (Czech Republic)

\section{Part A Quantum Optics and Quantum Information Transfer and Processing}

Conference Chair

Miloslav Dusek, Palacký University (Czech Republic)

Program Committee

Ulrik Andersen, Danmarks Tekniske Universitet (Denmark)

Markus Arndt, University of Vienna (Austria)

Jens Eisert, Imperial College London (United Kingdom)

Jaromír Fiurásek, Palacký University (Czech Republic)

Daniel F. James, University of Toronto (Canada)

Christian Kurtsiefer, National University of Singapore (Singapore)

Andreas Poppe, University of Vienna (Austria)

Fabio Sciarrino, Universitá degli Studi di Roma, La Sapienza (Italy)

Andrew J. Shields, Toshiba Research Europe Ltd. (United Kingdom)

Session Chairs

Quantum Cryptography and Quantum Information Processing

Miloslav Dusek, Palacký University (Czech Republic)

Quantum Entanglement and Quantum Optics

Zhiliang Yuan, Toshiba Research Europe Ltd. (United Kingdom) 


\title{
Part B Photon Counting Applications
}

\author{
Conference Chairs
}

Ivan Prochazka, Czech Technical University in Prague (Czech

Republic)

Roman Sobolewski, University of Rochester (United States)

Program Committee

Josef Blazej, Czech Technical University in Prague (Czech Republic)

Alan L. Migdall, National Institute of Standards and Technology (United States)

Ulrich Schreiber, Technische Universität München (Germany)

Wojciech Slysz, Instytut Technologii Elektronowej (Poland)

Michael Wahl, PicoQuant GmbH (Germany)

Session Chairs

Superconducting Photon Counters

Roman Sobolewski, University of Rochester (United States)

Semiconducting Photon Counters

Ivan Prochazka, Czech Technical University in Prague (Czech Republic)

Photon Counting Applications

Cesare Barbieri, Universitá degli Studi di Padova (Italy)

Semiconductor Photon Detectors

Josef Blazej, Czech Technical University in Prague (Czech Republic) 